University of Nebraska - Lincoln

DigitalCommons@University of Nebraska - Lincoln

The George Eliot Review

English, Department of

1997

\title{
Having The Whip-Hand in Middlemarch
}

Daniel Karlin

Follow this and additional works at: https://digitalcommons.unl.edu/ger

Part of the Comparative Literature Commons, Literature in English, British Isles Commons, and the Women's Studies Commons

Karlin, Daniel, "Having The Whip-Hand in Middlemarch" (1997). The George Eliot Review. 303.

https://digitalcommons.unl.edu/ger/303

This Article is brought to you for free and open access by the English, Department of at DigitalCommons@University of Nebraska - Lincoln. It has been accepted for inclusion in The George Eliot Review by an authorized administrator of DigitalCommons@University of Nebraska - Lincoln. 


\title{
HAVING THE WHIP-HAND IN MIDDLEMARCH
}

\author{
by Daniel Karlin
}

(This is the text of a paper given at the Victorian Studies Conference, University of Liverpool, 8 September 1996.)

In one of the first reviews of Proust's Du côté de chez Swann, appropriately published in the journal Le Temps, in 1913, the critic Paul Souday takes Proust to task for writing too much like an Englishman. 'His copious narratives have something of Ruskin and Dickens in them,' Souday remarks; and he might easily have added George Eliot, whom we know Proust to have read and admired. Souday goes on:

This superabundance of trivial events, this insistence on suggesting explanations of them, is frequently met with in English novels, where the sense of life is produced by a kind of assiduous cohabitation with the characters. We French and Latin folk prefer a more synthesising method. ${ }^{1}$

The question of what realism in fiction is, and whether indeed there can be said to be such a thing, is a perennial topic of criticism - one to which George Eliot herself notably contributed. I would like to offer Souday's back-handed phrase - 'the sense of life produced by a kind of assiduous cohabitation with the characters' - as a working definition, or at any rate adopt it as the motto for this essay. I take it that Souday's response to Proust would be generally disagreed with today, as indicating his failure to see the wood for the trees - a failure excusable in part, of course, by his having traversed only the first thicket of $A$ la recherche $d u$ temps perdu. But if anything, criticism of Proust has gone to the opposite extreme in its emphasis on design and control in a work which does, after all, luxuriate and proliferate with Dickensian or Ruskinian energy. My argument will be that in Middlemarch, too, the 'sense of life' is conveyed by a superabundance of trivial events, but that something else has its eye on this superabundance and may be said to have designs upon it.

I begin with an incident which takes place in Chapter 12 of Middlemarch. ${ }^{2}$ The scene is Stone Court, the residence of the old miser and misanthrope Peter Featherstone, and the occasion is the first meeting between Rosamond Vincy, who is Featherstone's niece, and Lydgate, who is his doctor. Lydgate comes in just as Rosamond is about to leave, and Featherstone mentions that she has been singing to him: she is, he boasts, the best in Middlemarch.

'Middlemarch has not a very high standard, uncle,' said Rosamond, with a pretty lightness, going towards her whip, which lay at a distance.

Lydgate was quick in anticipating her. He reached the whip before she did, and turned to present it to her. She bowed and looked at him: he of course was looking at her, and their eyes met with that peculiar meeting which is never arrived at by effort, but seems like a sudden divine clearance of haze. $(12,117)$ 
The meeting of Rosamond's and Lydgate's eyes may be unpremeditated, but the same cannot be said of the narrative of that meeting, or the dramatic irony which it enfolds. It is all about anticipation: the physical gesture on the part of the character is made to coincide with the writer's employment of prolepsis, the rhetorical figure of anticipation: power is to be an issue in Lydgate's relations with Rosamond, and in handing her the whip he is making a rod for his own back. She goes on to make use of the whip, mastering him in ways which he precisely does not anticipate; indeed, his quickness in anticipating her here is deceptive, just as her pretty lightness turns out to conceal an unbending will and grip. We can trace the figure all the way to the other end of the novel, to the moment in Chapter 78 when someone - but not Lydgate finally gets the whip-hand of Rosamond. This person is Will Ladislaw, and he does it with a metaphorical whip, with his voice, when he rejects the touch of her hand:

She put out her arm and laid the tips of her fingers on Will's coat-sleeve.

'Don't touch me!' he said, with an utterance like the cut of a lash... He wheeled round to the other side of the room and stood opposite to her, with the tips of his fingers in his pockets and his head thrown back. $(78,777)$

In the care with which the tips of Rosamond's fingers are opposed to the tips of Ladislaw's, the realism of both gestures (disposing us to believe them 'in character') is subsumed by a different design. This design is the subject of my essay. When Lydgate hands Rosamond her whip, he, too, is acting in character, yet his action has another quality. The 'touch' of the passage - spectral, disembodied, yet palpable and powerful - is that of the writer's hand.

I want to connect the fact that Middlemarch is George Eliot's handwork with the predominance, in the novel's system of representations, of hands and everything associated with them. I have seventy pages of extracts, a Casaubon-like heap of material, in which hands are mentioned: either directly, or by association with the actions and gestures they perform, or in a multitude of figurative expressions. ${ }^{3}$ Naturally I have a fine collection of whips, Rosamond's being in every way exceptional, since all the others in the novel belong to men; moreover they are singularly ineffectual in their use of them, except in one instance. Sir James Chettam, in Chapter 6, beats his whip nervously against his boot and then drops it when Mrs Cadwallader informs him of Dorothea's engagement to Casaubon (p. 58); Fred Vincy also beats his boot with his whip, in Chapter 12, as he is being tormented about money by his uncle Featherstone (p. 111), and sulkily takes up his hat and whip in Chapter 14, when Mary Garth rebuffs him (p.140); in Chapter 24, in the Garth family kitchen, his whip becomes a toy and he is embarrassed by one of the Garth children asking to be taken out riding, since it is because of his illadvised dealings in horse-flesh that he has got into debt and involved with Mr Garth in difficulty (p. 246). Later on, however - this is the instance I referred to - Fred uses his whip to good effect, when he chases the labourers in the field who have been harassing the railway men. (It's hard to take Fred seriously as a class warrior, and in fact George Eliot doesn't intend us to: she does the whole episode as burlesque, and its function in the plot is, paradoxically, to get the genteel Fred off his horse and into Caleb Garth's employment, where he works for a living with his hands.) Fred's sinking in the social scale is matched by Rosamond's rise, and 
she stigmatizes the vulgarity of the young men she is forced to frequent as 'Middlemarch gentry, elated with their silver-headed whips and satin socks, but embarrassed in their manners, and timidly jocose' $(27,267)$. The last (literal) whip in the novel, like the first, belongs to the unlucky Sir James, who hopes that scandal about Ladislaw being Rosamond's lover will put Dorothea off him; he sets up Mrs Cadwallader to mention this item of gossip, as though by accident, in the course of a walk, but he is embarrassed at his own underhand methods, and we see him 'turning aside to whip a shrub' when Mrs Cadwallader begins her story $(62,626)$.

The psychological acuteness of this last example, its concise rendering of embarrassment mixed with frustrated aggression (the 'shrub' is an image of Ladislaw himself in Sir James's mind as an upstart of no account) is what the novel is famous for, and is one of the defining elements of realist fiction - the fruit of George Eliot's 'assiduous cohabitation' with her characters. The episode in which Lydgate hands Rosamond her whip differs from this kind of realism, but is only enabled to do so by the mass of instances which conform to type. The same is true of other gestures: holding, clasping, pressing, shaking, and releasing hands, for example, which occur dozens of times, from St Teresa holding hands with her little brother in the Prelude (p. 3) to Fred grasping Mary's hand 'till it rather hurt her' in Chapter 86 (p. 830). Some of the novel's most heightened or poignant passages are marked by the touch of hands, such as the one at the end of Chapter 42 when Dorothea and Casaubon are momentarily and precariously reconciled ('She put her hand into her husband's, and they went along the broad corridor together', p. 427), or in the meeting of Dorothea and Rosamond in Chapter 81 ('Rosamond... could not avoid putting her small hand into Dorothea's which clasped it with gentle motherliness', p. 793) or during the culminating scene in Chapter 83 between Dorothea and Will, each of whose stages is marked by the holding or releasing of hands. A sub-set of this group concerns moments in which characters lay or put their hands on the hands of someone else. Almost always such moments represent ambivalent impulses, in which affection or even apology co-exists with the desire to dominate. Several times Dorothea lays her hand on Mr Casaubon's in this way, and he is stiffly sensitive to its implication: when she is talking of Will Ladislaw's decision to throw off his dependence on her husband, for example:

'I told him I was sure that the things you considered in all you did for him was his own welfare. I remembered your goodness in what you said about him when I first saw him at Lowick,' said Dorothea, putting her hand on her husband's.

'I had a duty towards him,' said Mr Casaubon, laying his other hand on Dorothea's in conscientious acceptance of her caress, but with a glance which he could not hinder from being uneasy. $(22,225)$

When, right at the end of the novel, Will lays his hand on Dorothea's, her hand 'turns itself upward to be clasped' $(83,811)$, her will corresponding to his, so that she is not claimed or imposed on. ${ }^{4}$

The precision of the physical notation in such passages, and the energy of mind and feeling 
with which it is charged, are typical of the novel's treatment of hands, and contrast with its relative lack of interest in, for example, the tones of the voice, or the movement and expression of other parts of the body. ${ }^{5}$ In turn, the characters notice and are interested in hands: when Sir James Chettam is paying unwanted court to Dorothea, she finds his 'dimpled hands ... quite disagreeable' $(3,30)$, while Lydgate's large white ones are attractive to Rosamond; she has already heard about them from Mary Garth, who mentions the new doctor's 'large solid white hands' in her description of him in Chapter 12 (p. 114). The whiteness of Lydgate's hands is a mark of social difference, almost of otherness: Rosamond contrasts them with the red hands of her other suitor, young Ned Plymdale, who belongs to the stratum of Middlemarch society from which she is determined to escape $(27,269)$. The painter Naumann notices Dorothea's 'beautiful ungloved hand' in Rome $(19,189)$; but we already know that Dorothea's hands would attract a painter, because that is the first definite thing which George Eliot tells us about her, in the second sentence of Chapter 1: 'Her hand and wrist were so finely formed that she could wear sleeves not less bare of style than those in which the Blessed Virgin appeared to Italian painters' (p. 7). In Chapter 4 we learn that these hands have a metaphysical as well as an aesthetic quality:

They were not thin hands, or small hands; but powerful, feminine, maternal hands. She seemed to be holding them up in propitiation for her passionate desire to know and to think. $(4,38)$

Rosamond's hands, needless to say, are thin and small, in a feminine but un-maternal way, and she is seen using them in the novel for three main purposes: to sew, to play the piano, and to touch herself, especially her 'wondrous hair-plaits - an habitual gesture with her as pretty as any movements of a kitten's paw' $(16,160) .{ }^{6}$ Rosamond's skill in music, by which the 'hidden soul' of her old music-master seems to be 'flowing forth from her fingers' $(16,161)$, raises some interesting questions about aesthetics and the body, but these are of limited significance in the novel; the portrayal of her narcissism is, as Rosemary Ashton remarks, too insistent, and is in danger of seeming as stereotyped as the gestures given to minor characters, such as the auctioneer Mr Trumbull, who is always seen 'trimming' himself with his forefinger and playing with his watch-seals. ${ }^{7}$ Rosamond's sewing, on the other hand, connects her to one of the book's central subjects. I am interested here not so much in the web as a governing metaphor as in the 'work' which the middle-class women characters are shown habitually doing with their hands. 'The constant references to women carrying, holding, picking up, laying down, getting on with or neglecting their 'work' are part of the novel's realism, its verisimilitude; moreover, George Eliot is attentive to the ways in which this habitual, almost necessary and unconscious activity of the hands becomes infused with individual and social character, so that when Mrs Garth lays down her knitting and folds her arms, it is described as 'an unwonted sign of emotion in her that she should put her work out of her hands' $(57,575)$, and the excitement of a fresh subject of gossip in Middlemarch is signalled by 'wives, widows, and single ladies [taking] their work and [going] out to tea oftener than usual' $(71,719)$. Women use their sewing as a weapon in conversation: Fred is on the receiving end of this from Mary Garth in Chapter 14 ('Mary was sewing swiftly, and seemed provokingly mistress of the situation', p. 138), and from her mother in Chapter 57 ('She was knitting, and could either look at Fred or 
not, as she chose', p. 573). But, as with the whip, the close notation of women's sewing is, at certain crucial moments, overdetermined, and bears the mark not of something observed to happen, but something made. It is important for the novel's purpose that these visionary interventions or intrusions should be disguised, so to speak, as contingent and probable, and so they seek safety in numbers. Since there are so many references to women sewing, it isn't surprising to find such a reference in the scene of Lydgate's involuntary proposal to Rosamond in Chapter 31, even if it turns out to repeat the episode of his handing her the whip and to mark his entry into servitude:

Miss Vincy was alone, and blushed so deeply when Lydgate came in that he felt a corresponding embarrassment, and instead of any playfulness, he began at once to speak of his reason for calling, and to beg her, almost formally, to deliver the message to her father. Rosamond, who at the first moment felt as if her happiness were returning, was keenly hurt by Lydgate's manner; her blush departed, and she assented coldly, without adding an unnecessary word, some trivial chain-work which she had in her hands enabling her to avoid looking at Lydgate higher than his chin. In all failures, the beginning is certainly the half of the whole. After sitting two long moments while he moved his whip and could say nothing, Lydgate rose to go, and Rosamond, made nervous by her struggle between mortification and the wish not to betray it, dropped her chain as if startled, and rose too, mechanically. Lydgate instantaneously stooped to pick up the chain. When he rose he was very near to a lovely little face set on a fair long neck which he had been used to see turning about under the most perfect management of self-contented grace. But as he raised his eyes now he saw a certain helpless quivering which touched him quite newly, and made him look at Rosamond with a questioning flash. $(31,300-1)$

I'm tempted to go off at a tangent here, leaving Lydgate to carry his chain, and pick up on the word 'management', whose root is the Latin manus, meaning hand: this is one of a series of allusions in the novel to the management of people, or property, or institutions such as the bank or the hospital. The management of people is manipulative: 'I shall leave you to manage your papa,' Rosamond's mother tells her. 'You always do manage everybody' (36, 344); and Celia, Dorothea's sister, flatters herself that 'None of them knew Dodo as well as she did, or know how to manage her' $(50,489)$. Unfortunately, though Rosamond can manage Lydgate, she cannot, as he exorts her to do, 'turn her mind to managing' $(58,595)$, in the sense of household economy. It is by proving himself 'hopelessly unmanageable' $(68,686)$ that Raffles provokes Bulstrode into defying him; Caleb Garth, on the other hand, is described as 'the most easily manageable man in the world' as far as his domestic arrangements go $(56,563)$, but not on matters of principle. Caleb believes passionately in good management: as he tells Mr Farebrother,

[']It's a most uncommonly cramping thing ... to sit on horseback and look over the hedges at the wrong thing, and not be able to put your hand to it to make it right. What people do who go into politics I can't think: it drives me almost mad to see mismanagement over only a few hundred acres.' $(40,405)$ 
Caleb is referring to Mr Brooke's neglect of his duties as a landlord, which becomes a liability in his election campaign: the link between management and its etymological root is pointedly made in Caleb's use of the idiom 'to put your hand to it'; and here I could go off at another tangent, or two, one of which is to do with idioms and phrases, such as having a hand in, being at hand, taking things into one's own hands, having one's hands full, washing one's hands of something or someone; the other, more interesting and lively, though scarce in the novel, is the politics of management and manufacture, and its relation to those who work with their hands: the 'wretched hand-loom weavers', for example, whom Mrs Cadwallader describes Mr Vincy as 'sucking the life out of' $(34,327)$, or the 'muster of working hands' in the hay-field $(55,549)$ who discuss the coming of the railway and end up be giving Fred Vincy the opportunity to use his whip. ${ }^{9}$

To return to Lydgate and Rosamond: the two episodes of whip and chain resemble each other not just in their external features (Lydgate hands something to Rosamond and their eyes meet) but in their production - by effort and intention - of a moment of unintended consequences. Although, in the first episode, the sense of being precipitated into something unforeseen is as strong in Rosamond as in Lydgate, in the second it is Lydgate's sensation which predominates, and it is of him that George Eliot remarks, in the next paragraph: 'He did not know where the chain went' $(31,301)$. Lydgate's ignorance, which of course implies the author's knowledge, is based on a delusion about what Rosamond is like; and this delusion is not particular and contingent, but the necessary product of a general idea. In demonstrating 'where the chain goes', the novel ironically echoes Lydgate's desire, as a scientist, to 'work out the proof of an anatomical conception and make a link in the chain of discovery' $(15,146)$ and juxtaposes this project with its own providential narrative, whose conception is there to be 'discovered' only in the sense of being revealed.

I want to illustrate this pressure of the writer's hand on the representation of character by following a sequence of gestures in which Lydgate and Rosamond are made, as it were, to collaborate in the unravelling of their lot. Rosamond's 'perfect management of self-contented grace' is what Lydgate has admired and found attractive in her, yet what touches him is not her management of her body, but her failure to manage it, the 'helpless quivering' which is the sign, as he believes, of her passionate dependence. In fact it is nothing of the sort: Lydgate is deceived first by Rosamond's self-control and then by her loss of it. The point is that both these things are aspects of a false consciousness which is predicated on the body and its appearances. There is something odd about Lydgate's professional passion for the body, his desire to understand its material principles, his explorations and experiments on the flesh, when you combine it with his ignorance of how the personal and social body actually works. In particular Lydgate does not understand how human beings exercise power over each other, a lack of understanding which costs him as dearly in his professional dealings with his male colleagues as it does in his personal relations with women.

From the moment he hands her the whip, the erotic charge in Lydgate's relationship with Rosamond is connected with the movement of his hands, whether he is scornfully turning the pages of the Keepsake and 'showing his large white hands to much advantage, as Rosamond 
thought' $(27,270)$, or 'bending his head to the table and lifting with his fourth finger her delicate handkerchief which lay at the mouth of her reticule, as if to enjoy its scent' $(31,293)$. But the erotic also implies the social, in ways which Lydgate does not appreciate, but which George Eliot pressingly invites her readers to take into account. Suppose we look again at the handkerchief incident, and bring in the surrounding context. Rosamond compliments Lydgate on the growth of his practice:

'... how your practice is spreading! You were called in before to the Chettams, I think; and now, the Casaubons.'

'Yes,' said Lydgate, in a tone of compulsory admission. 'But I don't really like attending such people so well as the poor. The cases are more monotonous, and one has to go through more fuss and listen more deferentially to nonsense.'

'Not more than in Middlemarch,' said Rosamond. 'And at least you go through wide corridors and have the scent of rose-leaves everywhere.'

'That is true, Mademoiselle de Montmorenci,' said Lydgate, just bending his head to the table and lifting with his fourth finger her delicate handkerchief which lay at the mouth of her reticule, as if to enjoy its scent, while he looked at her with a smile.

Seen in this light, Lydgate's gesture is a humorous one, paying mock-homage to Rosamond's taste for gracious living. The fourth, or little, finger is the least used, the least needed: it suggests that Lydgate would handle Rosamond as he does her handkerchief, taking pleasure in her delicacy, frivolity, and superfluous luxury, but not taking her seriously, and not peering further into the reticule than its mouth. He doesn't understand the import of Rosamond's comment about his aristocratic patients, and certainly doesn't appreciate the effect of his own aristocratic connections on her view of him.

The next time this subject comes up, at the end of Chapter 43, Lydgate and Rosamond are married. Rosamond teases Lydgate with his preoccupation with his work:

[']You are always at the Hospital, or seeing poor patients, or thinking about some doctor's quarrel; and then at home you always want to pore over your microscope and phials. Confess you like those things better than me.'

'Haven't you ambition enough to wish that your husband should be something better than a Middlemarch doctor?' said Lydgate, letting his hands fall on to his wife's shoulders, and looking at her with affectionate gravity. $(43,437)$

Lydgate uses both hands here, not just his fourth finger. I'm interested in the phrase 'letting his hands fall', which I connect with Lydgate's affectionate gravity: Lydgate is in earnest, and expects his earnestness to act on Rosamond as though it were, like gravity, an impersonal and 
necessary force. Suppose we move on to Chapter 58: we are in the first period of Lydgate's disillusion with Rosamond, his realization that she has a will of her own. The differing value which he and Rosamond place on social rank has now become a matter of real dispute, focusing on Lydgate's contempt for his cousin, Captain Lydgate, the third son of a baronet and in Lydgate's opinion a 'conceited ass' (p. 582). But Rosamond rebukes him:

'I cannot conceive why you speak of your cousin so contemptuously,' said Rosamond, her fingers moving at her work while she spoke with a mild gravity which had a touch of disdain in it. (p. 583)

Gravity is now on Rosamond's side: the movement of her fingers and the 'touch of disdain' increase the sense of its being a physical force. When Lydgate, soon after, urges her not to go out riding with Captain Lydgate because of the risk to her pregnancy, Rosamond responds with a revisionary gesture to the one in which Lydgate had let his hands fall on her shoulders:

Rosamond was arranging her hair before dinner, and the reflection of her head in the glass showed no change in its loveliness except a little turning aside of the long neck. Lydgate had been moving about with his hands in his pockets, and now paused near her, as if he waited some assurance.

'I wish you would fasten up my plaits, dear,' said Rosamond, letting her arms fall with a little sigh, so as to make a husband ashamed of standing there like a brute. Lydgate had often fastened the plaits before, being among the deftest of men with his large finely-formed fingers. He swept up the soft festoons of plaits and fastened in the tall comb (to such uses do men come!); and what could he do then but kiss the exquisite nape which was shown in all its delicate curves? But when we do what we have done before, it is often with a difference. $(58,585)$

By 'letting her arms fall', Rosamond compels Lydgate to take his hands out of his pockets, and to touch her in a way which she, and not he, has designed. George Eliot is suggesting, not that Lydgate takes no pleasure in fastening up Rosamond's plaits and kissing her exquisite nape, but that he is being compelled to substitute this pleasure for the 'assurance' he wanted of her compliance. In fact the service which Lydgate performs for Rosamond with his hands is an emblem of his having no hold over her. As the marriage decays, the struggle for power becomes the preoccupation of both husband and wife, and, in Chapter 64, we see Lydgate moving rapidly from tender condescension to a violent assertion of his authority.

Attempting to persuade Rosamond that they must live more cheaply, he begins by cajoling her: 'he held her waist with one hand and laid the other gently on both of hers; for this rather abrupt man had much tenderness in his manners towards women, seeming to have always present in his imagination the weakness of their frames and the delicate poise of their health both in body and mind' (p. 649). Lydgate's actions, of holding Rosamond by the waist and laying his hand on both of hers, are prompted by a fundamental misconstruing of female nature in general, and 
Rosamond's in particular. The bitter pill he is asking her to swallow is to give up their house and furniture to Ned Plymdale, her old suitor - he of the red hands - who is prospering in trade and has married a lesser Middlemarch beauty. Lydgate is as ignorant of the nature of this humiliation as Rosamond is of the one she enjoins on him, to ask his family for money, to affirm his loyalty to the social rank into which she thought she was rising when she married him:

'You will not behave as you ought to your own family. You offended Captain Lydgate. Sir Godwin was very kind to me when we were at Quallingham, and I am sure if you showed proper regard to him and told him your affairs, he would do anything for you. But rather than that, you like giving up our house and furniture to Mr Ned Plymdale.'

There was something like fierceness in Lydgate's eyes, as he answered with new violence, 'Well then, if you will have it so, I do like it ...Understand then, that it is what I like to do.'

There was a tone in the last sentence which was equivalent to the clutch of his strong hand on Rosamond's delicate arm. But for all that, his will was not a whit stronger than hers. $(64,651)$

The relationship between Lydgate and Rosamond has come down to this 'clutch of his strong hand', which is a sign not of power but of impotence. In fact it is Rosamond who clutches Lydgate to real purpose: in one of the novel's starkest reversals, Lydgate discovers that 'the need of accommodating himself to her nature, which was inflexible in proportion to its negations, held him as with pincers' $(65,666)$. These pincers, figurative and mechanical hands, extend Rosamond's power into the operations of Lydgate's mind. At the end of Chapter 65, when Rosamond breaks down in tears, Lydgate's surrender to her is signalled by the very gestures with which he had earlier tried to bend her will.

Lydgate drew his chair near to hers and pressed her delicate cheek against his cheek with his powerful tender hand... He wished to excuse everything in her if he could - but it was inevitable that in that excusing mood he should think of her as if she were an animal of another and feebler species. Nevertheless she had mastered him. $(65,667)$

Reminding us at this moment that Lydgate's hand is physically powerful exactly measures his lack of power, a lack which is once again, and decisively, attributed to his defective understanding. He holds Rosamond's body as close as he likes, he continues to manipulate her, but she is beyond his grasp. This is where the chain goes, the chain which Lydgate did not perceive at the beginning, but which the writer had already forged.

It could be argued that mastery in the novel belongs not to the characters who struggle for it, but to the writer whose grasp exceeds their reach. Yet the book is very anxious about power, 
and tells us that no good comes of trying to exercise it. It is especially anxious about writing. The figure of Mr Casaubon stands as a warning of what happens to the writer who both appeals to authority and tries to impose it by means of a systematic, monumental, and abstract text. Dorothea, when she replies to Mr Casaubon's proposal, writes out her answer three times:

not because she wished to change the wording, but because her hand was unusually uncertain, and she could not bear that Mr Casaubon should thing her handwriting bad and illegible. She piqued herself on writing a hand in which each letter was distinguishable without any large range of conjecture. $(5,45)$

Dorothea wants to put this clear and unambiguous handwriting at the service of Mr Casaubon; on their honeymoon in Rome, she presses him to 'begin to write the book which will make your vast knowledge useful to the world', and promises to 'write to your dictation, or I will copy and extract what you tell me' $(20,200)$. But the 'Key to all Mythologies' turns out to consist of 'mixed heaps of material, which were to be the doubtful illustration of principles still more doubtful' $(48,478)$. Mr Casaubon has managed the feat of devising a text which is dogmatic, oppressive, and yet without authority. Nor is the 'Key to all Mythologies' the only such text: there is also his will. Book Five of the novel is called 'The Dead Hand', a title which alludes both to Mr Casaubon's attempt to make Dorothea complete his futile work of scholarship after his death, and also to the codicil which he adds to his will and which disinherits her if she marries Ladislaw. By such means, we are told, Casaubon seeks 'to keep his cold grasp on Dorothea's life' $(50,493)$ : the use of the word keep ironically suggests that she wouldn't notice the difference. Mr Casaubon's hand has always been dead, just as the texts he studies are 'shattered mummies, and fragments of a tradition which was itself a mosaic wrought from crushed ruins' $(48,478) .{ }^{10}$ By his own admission he 'live(s) too much with the dead' $(2,18)$, and the task he wants Dorothea to perform is to 'erect a tomb with his name upon it' $(50,493)$. Mr Casaubon is worse off than Dorothea, whose obscure life is recuperated in the last words of the novel: she may rest in an unvisited tomb, but Mr Casaubon's textual tomb will not even be built.

The contrast with the novel itself is striking. If it is a tomb with George Eliot's name upon it, then it looks likely to be visited for as long as we can imagine. In this sense Eliot has avoided the fate of both Casaubon and Dorothea. She has also eschewed Lydgate's scientific researches. Lydgate is not the answer to Casaubon; if anything he is his mirror-image. He, too, lives among the dead - as is comically brought home by the scandal spread by Mrs Dollop, the landlady of the Tankard in Slaughter Lane, who firmly believes that 'Doctor Lydgate meant to let the people die in the Hospital, if not to poison them, for the sake of cutting them up without saying by your leave or with your leave'; and, Mrs Dollop shrewdly adds, it was 'a poor tale for a doctor, who if he was good for anything should know what was the matter with you before you died, and not want to pry into your inside after you were gone' (45, 442-3).

Perhaps such knowledge belongs to the novelist - especially the kind of novelist George Eliot sets out to be. After all the word life in the subtitle of the novel - 'A Study of Provincial Life' - quietly makes the point that the book is going to conduct its business among the living. 
What limits both Casaubon and Lydgate, and arguably Dorothea as well, is an inadequate knowledge of the conditions of life, whether provincial or not. Lydgate's knowledge of Rosamond is specifically related to this point: he thinks that she has 'just the kind of intelligence one would desire in a woman ... enshrined in a body which expressed this with a force of demonstration that excluded the need for other evidence' $(16,164)$. In the very next paragraph we see him in his bachelor quarters, reading a new book on fever, and

bringing a much more testing vision of details and relations into this pathological study than he had ever thought it necessary to apply to the complexities of love and marriage, these being subjects on which he felt himself amply informed by literature, and that traditional wisdom which is handed down in the genial conversation of men.

Realism is a corrective mode, therefore, bringing a 'testing vision of details and relations' to the study of the social body and the socialized bodies of men and women. But such representation has its limits. It is not such a great thing to represent Middlemarch, either aesthetically or politically - one of the last things we are told in the book is that Dorothea's son inherits $\mathrm{Mr}$ Brooke's estate and 'might have represented Middlemarch, but declined, thinking that his opinions had less chance of being stifled if he remained out of doors' (Finale, 837). This is an impulse felt also, I think, by the novelist, who fears stifling as a representative writer.

It may therefore make sense to construe the book's realism as a project of escape or evasion of the dead hand of writing, and its providential narrative as the horizon which circumscribes that project. The moments in which this providential narrative makes itself manifest are, as I have suggested, hidden in the book, because George Eliot cannot claim an authority for it, textual or otherwise. She is standing neither on Milton's ground nor on Fielding's: her 'presence' in the narrative, her visibility or palpability as its controlling force, is an issue so fraught with difficulty that she devotes an extraordinary passage of the novel to disavowing it. At the beginning of Chapter 15, and ostensibly to mark the transition from one part of the plot to another, she looks back at the eighteenth-century novel with affection, with envy, with resentment, and with an acute consciousness of her own dilemma:

A great historian, as he insisted on calling himself, who had the happiness to be dead a hundred and twenty years ago, and so to take his place among the colossi whose huge legs our living pettiness is observed to walk under, glories in his copious remarks and digressions as the least imitable part of his work, and especially in those initial chapters to the successive books of his history, where he seems to bring his arm-chair to the proscenium and chat with us in all the lusty ease of his fine English. But Fielding lived when the days were longer (for time, like money, is measured by our needs), when summer afternoons were spacious, and the clock ticked slowly in the winter evenings. We belated historians must not linger after his example; and if we did so, it is probable that our chat would be thin and eager, as if delivered from a camp-stool, in a parrot-house. I at least have so much to do in unravelling certain human 
lots, and seeing how they were woven and interwoven, that all the light I can command must be concentrated on this particular web, and not dispersed over that tempting range of relevancies called the universe. $(15,141)$

This is a passage with its own tempting range of relevancies, but I want to concentrate my light on the contrast between the early and belated writing, and on the very curious and suggestive appeal to historical change as a way of accounting for it. The greater pace and stress of modern life was as much a commonplace for the Victorians as it is for us, and it is their spacious summer afternoons and long winter evenings that we look back on: Eliot wouldn't be surprised by this, since she herself points out that the sense of time is relative. We are accustomed to thinking of our situation, however, in terms of a dwindling of our attention-span, a condition supposedly made worse by television and sound-bite culture, so that we find it hard to take in long novels, whereas Eliot's point is not that she is driven to write shorter books Middlemarch is not in fact much shorter than Tom Jones - but that she is no longer able to write that kind of book - the kind of book in which the author 'seems to bring his arm-chair to the proscenium', in other words draws attention to the fictionality of his story and to his own command over it. In Fielding's case, this command is expressed not just in the despotic ordering of the plot, but in his freedom to abandon the plot altogether and 'chat' about whatever he likes. He is not subject to his own story, whereas Eliot implies that hers is a task, that she has her hands full and hasn't the leisure to neglect it. His work is a performance; hers a work that she performs. The greater leisure which Fielding's readers enjoyed is also his own: that is, the long summer afternoons and winter evenings figure a space for writing in which its authority is assumed and exercised without constraint.

But at this point a troubling difficulty enters the argument. For George Eliot begins by reminding us that Fielding, an ancestral figure in the line of realist fiction, 'insisted on calling himself [a historian]' and his fiction a history. She herself, with whatever ambivalence, is affiliated to this tradition - a 'belated historian', perhaps, but one who accepts the designation. Clearly a historian has no business bringing his arm-chair to the proscenium, yet Fielding does so and stands in a position of power, simultaneously enjoining and forbidding his successors to imitate him. George Eliot's image of the task placed in her hands, the 'unravelling [of] certain human lots, and seeing how they were woven and interwoven', transforms the contradiction on which Fielding unselfconsciously depends into a paradox: she achieves mastery over her text by mystifying the source of her authority. The use of the word 'lots' to signify human destinies, the outcomes of human stories, is biblical and providential in its associations, and the task of unravelling them is given to the novelist, who forgets to mention that she has done the original weaving and interweaving with her own hands.

Notes

1. Cited in the edition by J. Milly et al. (Garnier-Flammarion, 1987), p. 656. The review appeared in Le Temps, 13 December 1913. The translation is mine.

2. All references are by chapter and page number to Rosemary Ashton's edition of the 
novel (Harmondsworth, 1994).

3. By 'figurative' I mean such passages as the following: 'Mr Casaubon seemed even unconscious that trivialities existed, and never handed round that small-talk of heavy men which is as acceptable as stale bride-cake brought forth with an odour of cupboard' $(3,33)$.

4. Contrast Celia's 'little hands ... clasped, and enclosed by Sir James's as a bud is enfolded by a liberal calyx' $(29,284)$.

5. This is true even of the face and eyes, though of course these receive what you might call their normal allowance of attention.

6. Her reaching out to touch Ladislaw in Chapter 78, though not improbable, is unusual for Rosamond: on most occasions in the novel she waits to be touched or reached out for.

7. See Rosemary Ashton's introduction to the Penguin Classics edition (1994), p. xv. Mr Trumbull is seen 'trimming himself rapidly with his forefinger, and marking each new series in these movements by a busy play with his large seals' $(32,310)$; 'playing with his seals dispassionately' (ibid.); 'patrolling with his forefinger round the inside of his stock, than along his whiskers and the curves of his hair' $(32,311)$; 'handling his watch-seals and trimming his outlines' $(35,333)$; 'trimming his outlines with his left finger' $(60,605)$; 'trimming and comporting himself with an eager solicitude' (64, 654). These references comprise all his appearances in the novel. I would guess that George Eliot picked up this practice from Dickens.

8. The strong association between sewing and women's work is, not surprisingly, challenged only by Dorothea: in Chapter 54 she is in her boudoir, and 'had not yet applied herself to her work, but was seated with her hands folded on her lap'; but this 'work' is to do with 'a map of the land attached to the manor and other papers ... which were to help her in making an exact statement for herself of her income and affairs' (p.540).

9. The sharp reminder of how the Vincys make their money strikes a note of modernity in the novel which accords very ill with the episode of old Peter Featherstone, a figure out of Molière or Ben Jonson, with his greedy relatives and his hands clutching banknotes and piles of gold. In addition to Fred, it's worth remarking that he comes from what is described as a Middlemarch family of 'old manufacturers' (11, 96; manufacture is another word which stems from manus) and ends up as the manager, rather than the owner, of Featherstone's estate at Stone Court.

10 Casaubon's writings are the major, but by no means the only, example in the novel of a textual authority which is both oppressive and uncertain. A minor, but very telling example is the document which Featherstone requires Fred Vincy to obtain from $\mathrm{Mr}$ 
Bulstrode, supposedly as proof that Fred has not been borrowing money on the expectation of inheriting Featherstone's estate. Fred has to get his father to persuade Bulstrode to write the document, which Featherstone knows perfectly well has no value as evidence: the circle is completed when Featherstone gives Fred permission to burn it. 